\title{
Efektivitas Penggunaan Instagram Stories Pada Akun @male.id Terhadap Pembentukan Brand Awareness dan Minat Beli di Kalangan Mahasiswa Universitas Islam Indonesia
}

\section{The Effectiveness Of Using Instagram Stories On@male.id's Account For The Formation Of Brand Awareness And Purchase Intention Among The Students Of Islamic University Of Indonesia}

\author{
Putra Muhammad Dafa', Puji Hariyanti² \\ ${ }^{1,2}$ Program Studi Ilmu Komunikasi, Universitas Islam Indonesia, Sleman \\ Yogyakarta, Indonesia
}

\section{Author's email:}

${ }^{1}$ Email:

17321081@students.uii.ac.id

${ }^{2}$ Email:

puji.hariyanti@uii.ac.id

\begin{abstract}
:
Male.id as a local male fashion brand uses Instagram stories as a medium to introduce or promote their products to public and also to engage followers to interact by online. Therefore, this research is being done to analyze how effective the use of Instagram stories on @male.id's account for the formation of brand awareness and purchase intention among the students of Islamic University of Indonesia. This research is a survey research with a quantitative approach, so the datas were collected by distributing questionners to 100 respondents who are determined through a nonprobability sampling technique in the form of snowball sampling to be sampled. This research shows that the use of Instagram on @male.id's account is significantly effective and positive for the formation of brand awareness and purchase intention among students of Islamic University of Indonesia.
\end{abstract}

Keywords: brand awareness, male.id, purchase intention, the use of Instagram stories

\begin{abstract}
Abstrak:
Male.id sebagai brand fashion lokal pria menggunakan Instagram stories sebagai media dalam mengenalkan atau mempromosikan produknya kepada khalayak luas serta untuk melibatkan followers dalam berinteraksi secara online. Untuk itu, penelitian ini dilakukan guna menganalisis_seberapa besar efektivitas penggunaan Instagram stories pada akun @male.id terhadap pembentukan brand awareness dan minat beli di kalangan mahasiswa Universitas Islam Indonesia. Penelitian ini merupakan penelitian survei dengan pendekatan kuantitatif, sehingga data dikumpulkan melalui penyebaran kuesioner kepada 100 responden yang ditentukan melalui teknik nonprobability sampling berupa snowball sampling untuk dijadikan sampel. Penelitian ini menunjukkan bahwa penggunaan Instagram stories pada akun @ male.id efektif secara signifikan dan positif terhadap pembentukan brand awareness dan minat beli di kalangan mahasiswa Universitas Islam Indonesia.
\end{abstract}

Kata kunci: brand awareness, male.id, minat beli, penggunaan Instagram stories 


\section{PENDAHULUAN}

Internet sebagai salah satu produk teknologi mampu memudahkan manusia dalam hal mengakses informasi serta berkomunikasi. Komunikasi tidak dilakukan semata face to face atau bertemu langsung, melainkan dapat secara online tanpa batasan ruang dan waktu. Tidak hanya itu, internet telah menjadi institusi bisnis atau setidaknya sebagai sarana dalam memasarkan sebuah produk bagi para pelaku bisnis.

Dalam dunia bisnis, media sosial telah dimanfaatkan untuk mengenalkan dan memromosikan produknya kepada khalayak luas. Selain itu, perusahaan dapat memanfaatkan media sosial sebagai sarana untuk melibatkan konsumen dalam berinteraksi secara online. Dengan begitu, diharapkan dapat menciptakan hubungan yang baik dan berkelanjutan antara perusahaan dengan konsumen.

Salah satu media sosial yang paling banyak digunakan dalam melakukan pemasaran, yaitu Instagram. Instagram merupakan salah satu aplikasi media sosial yang digunakan untuk mengunggah, dan melihat foto pribadi yang dapat terhubung dengan teman hingga keluarga kapan pun dan dimana pun (Tanjaya, 2017). Kini, Instagram tidak hanya digunakan sebagai sarana untuk mengekspresikan diri dan bersosialisasi di dunia maya saja, melainkan juga dapat dimanfaatkan oleh sebagian orang untuk melakukan pemasaran serta transaksi jual beli sebuah produk, atau istilah tersebut biasa dikenal dengan online shop (Miranda \& Lubis, 2017). Kehadiran Instagram membuat para pelaku bisnis berlomba-lomba dalam menarik konsumen melalui fitur-fitur yang ditawarkan, mulai dari feeds hingga Instagram stories. Salah satu merek yang menggunakan Instagram sebagai media untuk mengenalkan dan mempromosikan produknya, yaitu Male.id.

Male.id merupakan salah satu brand fashion lokal pria yang mengusung konsep "basic club". Dengan konsep tersebut, produkproduk yang dibuat dapat dipastikan berwarna basic dan polos. Dalam aktivitasnya, Male.id melakukan penjualan secara online melalui Instagramnya. Selanjutnya, @male.id mengarahkan konsumen ke website heymale.id ketika akan diadakan "open order" terjadwal. Sistem open order terjadwal di Male.id merupakan adaptasi dari pola yang biasa dilakukan oleh brand perempuan (Brodo, 2020).

Menyangkut aktivitas dalam mengenalkan dan memromosikan produk yang ditawarkan, Male.id sangat aktif menggunakan fitur Instagram stories. Instagram stories merupakan salah satu fitur yang dimiliki oleh Instagram, di mana melalui fitur tersebut seseorang dapat membagikan cerita berupa foto maupun video yang diunggah dan dapat dilihat oleh followers-nya, kemudian akan hilang dalam waktu 24 jam (Anjani, 2019).

Selain sebagai sarana mengenalkan dan mempromosikan produk, Male.id juga menggunakan Instagram stories sebagai media dalam melibatkan followers untuk berinteraksi secara online seperti mengajak "ngobrol". Interaksi yang dilakukan melalui Instagram stories biasanya menampilkan screenshot-an direct message (DM) berupa honest review (testimoni) hingga pertanyaan dari followers yang kemudian ditambahkan teks sebagai balasan untuk DM tersebut. Selain itu, Male.id juga memanfaatkan fitur question box di Instagram stories untuk tanya jawab seputar Male.id maupun hal lainnya terutama ketika menjelang open order maupun setelahnya. Ini dapat menjadi salah satu konten yang menarik bagi para pengikut dari Male.id sendiri. Dengan aktif berinteraksi melalui Instagram stories, memungkinkan untuk membentuk brand awareness dan minat beli bagi konsumen/followers terutama di kalangan pria yang menyukai pakaian dengan warna basic.

Sebagai kalangan yang "melek" terhadap teknologi dan hal yang berkaitan dengan internet, membuat istilah online shop sangat 
lazim bagi mahasiswa. Selain itu, mahasiswa juga merupakan salah satu kalangan yang berpotensi aktif di situs jejaring sosial (Miranda \& Lubis, 2017). Dengan begitu, dapat membuka peluang bagi para pelaku bisnis termasuk Male.id untuk membentuk brand awareness, dan minat beli terutama di kalangan mahasiswa dengan aktif berinteraksi melalui Instagram stories.

Dipilihnya mahasiswa Universitas Islam Indonesia tentunya agar mampu memudahkan peneliti dalam melakukan penelitian. Di samping itu, dengan merujuk penelitian yang dilakukan oleh Anatasya (2018), di mana temuan penelitian tersebut memperlihatkan bahwa mahasiswa Universitas Islam Indonesia pengguna online shopping memiliki minat beli produk online yang tinggi. Penelitian yang dilakukan oleh Ardiansyah (2016) juga menemukan bahwa mahasiswa Universitas Islam Indonesia memiliki minat beli pada online shop yang tinggi.

Penelitian ini dilakukan untuk mengetahui seberapa besar efektivitas penggunaan Instagram stories pada akun @male.id terhadap pembentukan brand awareness, dan minat beli di kalangan Universitas Islam Indonesia. Penelitian ini bertujuan untuk menganalisis seberapa besar efektivitas penggunaan Instagram stories pada akun@male.id terhadap pembentukan brand awareness dan minat beli di kalangan mahasiswa Universitas Islam Indonesia.

Melalui penelitian ini, diharapkan dapat memberikan kontribusi dalam memperkaya pengetahuan serta wawasan dalam bidang ilmu komunikasi. Penelitian ini juga diharapkan dapat bermanfaat bagi para pemilik brand yang bergelut di Instagram. Pemilik brand dapat mengetahui seberapa efektifnya penggunaan fitur Instagram stories terhadap pembentukan brand awareness dan minat beli sehingga hal tersebut dapat dijadikan pertimbangan sebagai salah satu cara dalam membentuk brand awareness, dan minat beli pada konsumen terhadap produk yang ditawarkan.
Penelitian mengenai brand awareness sebelumnya sudah pernah dilakukan oleh Kristiawan (2015) yang memilih Uniqlo sebagai objek penelitian. Penelitian tersebut menunjukkan bahwa pemasaran melalui media sosial dapat memberitahukan keberadaan Uniqlo kepada khalayak atau mampu menciptakan kesadaran konsumen terhadap merek Uniqlo. Selain itu, penelitian tersebut memperlihatkan bahwa customer engagement atau keterlibatan konsumen dalam berinteraksi juga memberikan pengaruh yang signifikan terhadap kesadaran konsumen atas sebuah merek.

Penelitian terkait minat beli juga sudah pernah dilakukan sebelumnya oleh Septiawan (2016) dengan memilih produk fashion sneaker sebagai objek penelitian, di mana dalam penelitian tersebut menunjukkan bahwa terdapat hubungan yang cukup kuat antara efektivitas media sosial Instagram dengan minat beli sepatu sneaker. Arifin (2015) juga telah melakukan penelitian terkait minat beli dengan memilih objek penelitian, yakni brand Brodo Footwear. Penelitian tersebut menunjukkan bahwa terdapat hubungan yang rendah, tetapi pasti antara strategi pemasaran Brodo Footwear melalui Instagram dan minat beli. Selain itu, Nafisah (2018) juga telah meneliti terkait minat beli dengan menjadikan produk pakaian wanita Aris Grosir sebagai objek penelitian. Hasil penelitian tersebut memperlihatkan bahwa terdapat pengaruh antara strategi promosi melalui media sosial terhadap minat beli konsumen. Penelitian yang berkaitan dengan minat beli juga sudah pernah dilakukan oleh Anjani (2019) yang memilih salah satu produk kosmetik yaitu BLP Beauty sebagai objek penelitian. Hasil yang diperoleh menunjukkan bahwa terdapat pengaruh efektivitas konten media sosial Instagram @blpbeauty terhadap tingkat minat beli produk.

Sehubungan dengan yang telah dipaparkan, penelitian ini membahas topik yang serupa dengan beberapa penelitian sebelumnya. Hanya saja, penelitian ini tidak 
membahas mengenai media sosial Instagram secara umum, melainkan lebih berfokus pada salah satu fiturnya yakni Instagram stories sebagai media dalam melakukan promosi produk dan juga berinteraksi dengan followers yang dilakukan oleh akun @male.id, sehingga hal tersebut menjadikan penelitian ini memiliki sisi kebaruan dari penelitian-penelitian sebelumnya.

\section{KERANGKA TEORI}

Penelitian ini menggunakan konsep bauran pemasaran yang di dalamnya terdapat elemen promosi (promotion). Saat ini, aktivitas promosi tidak hanya sebatas offline saja, melainkan juga dapat dilakukan secara online atau yang dikenal dengan internet marketing. Aktivitas internet marketing dapat dilakukan dengan memanfaatkan fitur Instagram stories yang dimiliki oleh Instagram.

Penggunaan Instagram stories berarti menggunakan fitur Instagram stories sebagai media dalam menyampaikan informasi atau mempromosikan terkait sebuah produk kepada khalayak luas sehingga mampu mencapai tujuan pemasaran dari perusahaan tersebut. Di sisi lain, penggunaan Instagram stories juga dapat dilakukan sebagai media untuk membangun serta mempertahankan hubungan dengan para konsumen maupun calon konsumen, yang nantinya diharapkan mampu memberikan hasil berupa kesadaran merek maupun minat beli terhadap produk.

Penting bagi sebuah perusahaan untuk dapat memberikan informasi atas produknya kepada khalayak, sehingga dapat menimbulkan pemahaman atas produk tersebut yang nantinya dapat membentuk brand awareness pada konsumen. Pengetahuan dan pemahaman yang didapatkan oleh konsumen atas produk suatu perusahaan nantinya mampu membentuk kesadaran merek atau brand awareness pada konsumen tersebut (Pranata \& Pramudana, 2018).

Fauzi \& Lubis (2016) menyebutkan bahwa brand awareness adalah bagaimana kekuatan dari sebuah brand berada di dalam ingatan seseorang, apakah seseorang tersebut dengan mudah untuk mengingat sebuah brand atau justru sebaliknya. Dalam hal melihat seberapa baik brand awareness yang dimiliki seseorang terhadap suatu merek, maka Fauzi \& Lubis (2016) mengemukakan empat tingkatan dari brand awareness itu sendiri, yaitu:

a. Unaware of brand. Pada tingkatan yang paling rendah ini konsumen sama sekali tidak mengenali atau menyadari akan adanya suatu merek.

b. Brand recognition. Tingkatan ini terjadi jika konsumen telah menyadari akan adanya suatu brand, namun masih perlu diberikan bantuan terlebih dahulu berupa ciri-ciri produk brand tersebut seperti nama maupun tampilan visual produk.

c. Brand recall. Konsumen berada di tingkatan ini apabila dapat mengingat atau menyebutkan sebuah brand sebagai bagian dari kategori produk tertentu.

d. Top of mind. Pada tingkatan ini, sebuah brand telah melekat di benak konsumen, kemudian merek tersebut secara spontan dan pertama kali disebutkan sebagai suatu kategori produk tertentu.

Penting juga bagi sebuah perusahaan untuk melakukan penanaman dan penciptaan suatu ingatan tentang produknya dalam benak konsumen sehingga dapat meningkatkan upaya minat beli dari konsumen terhadap produk yang ditawarkan. Nafisah (2018) menyebutkan bahwa persepsi individu terkait produk dari sebuah perusahaan nantinya akan berpengaruh terhadap minat beli yang muncul di dalam diri individu tersebut.

Kusumasari (2018) menyebutkan bahwa minat beli adalah kecenderungan sikap konsumen untuk membeli suatu produk namun belum sampai pada keputusan pembelian. Menurut Nafisah (2018) minat beli merupakan sebuah perilaku konsumen yang menunjukkan bahwa konsumen memiliki keinginan untuk membeli atau memilih suatu produk. Keinginan tersebut didasarkan pada pengalaman dalam memilih, menggunakan (mengkonsumsi) atau bahkan menginginkan suatu produk. Minat beli konsumen terhadap sebuah produk juga tidak 
terlepas dari keputusan pembelian, karena minat merupakan salah satu proses dari pengambilan keputusan yang dilakukan oleh konsumen. Proses dari keputusan pembelian juga bergantung pada respons konsumen berdasarkan pada model AISAS.

Oktavia (2019) menjelaskan model AISAS yang merupakan singkatan dari Attention, Interest, Search, Action, dan Share. Di mana seseorang mampu menaruh perhatian pada produk yang disampaikan atau diiklankan oleh suatu brand (Attention), kemudian akan menimbulkan ketertarikan (Interest) pada produk tersebut dan muncul keinginan untuk mengetahui lebih lanjut. Dengan begitu, seseorang tersebut akan melakukan pencarian dan mengumpulkan informasi (Search) terkait produk yang diinginkan. Selanjutnya konsumen melakukan tindakan (Action) setelah mendapatkan informasi yang dirasa cukup mengenai produk yang diinginkan. Pada tahap ini pengalaman antara konsumen dengan perusahaan tercipta. Setelah melakukan pembelian dan merasa puas terhadap pengalaman yang didapatkan, selanjutnya akan mendorong konsumen untuk membagikan pengalaman atau informasi (share) kepada orang lain, baik di dunia nyata maupun secara online.

\section{METODE}

Peneliti menggunakan penelitian survei dengan pendekatan kuantitatif dalam penelitian ini. Penelitian survei digunakan karena peneliti ingin melakukan penelitian dalam skala besar atau populasi tertentu, namun data atau informasi hanya diambil dari responden yang telah dijadikan sampel.

Melalui akun Instagram Male.id, dapat diketahui bahwa Male.id memiliki total followers berjumlah 624 ribu (20 Maret 2021). Jadi, populasi penelitian ini sejumlah 624 ribu orang. Mengingat jumlah populasi yang banyak, peneliti menggunakan sampel sebanyak 100 responden yang merupakan mahasiswa Universitas Islam Indonesia dan mengikuti akun Instagram @male.id. Pengambilan sampel sejumlah 100 responden ditetapkan peneliti melalui pengoperasian rumus slovin sebagai berikut.

$$
\begin{aligned}
& n=\frac{N}{1+N \times e^{2}} \\
& n=\frac{624000}{1+624000 \times 10 \%^{2}} \\
& n=\frac{624000}{1+6240} \\
& n=\frac{624000}{6241} \\
& n=99.98 \\
& \text { Keterangan: } \\
& n=\text { Jumlah Sampel } \\
& N=\text { Jumlah Populasi } \\
& e=\text { Margin of Error sebesar } 10 \%
\end{aligned}
$$

Berdasarkan pengoperasian rumus tersebut, diperoleh jumlah sampel sebanyak 100 responden melalui pembulatan angka 99.98. Penentuan sampel berjumlah 100 responden juga dikarenakan sampel minimum untuk penelitian survei adalah 100 responden. Hal ini juga didukung oleh pernyataan Aditi \& Hermansyur (2018: 66) bahwa untuk memberikan hasil yang lebih baik adalah dengan menggunakan sampel minimal sebanyak 100 responden.

Pengambilan 100 responden sebagai sampel dalam penelitian ini menggunakan teknik nonprobability sampling berupa snowball sampling. Snowball sampling sendiri adalah teknik penentuan sampel dengan jumlah yang awalnya kecil, kemudian menjadi besar, ibarat bola salju yang menggelinding kemudian lama-lama menjadi besar Sugiyono (2019: 85). Merujuk pada hal tersebut, peneliti akan mencari beberapa orang yang diketahui oleh peneliti bahwa orang-orang tersebut mengikuti/ follow akun@male.id. Kemudian dari orang tersebut, digali informasi siapa teman atau teman-temannya yang juga mengikuti/ follow akun @male.id. Seterusnya hingga sampel dirasa cukup untuk mencapai jumlah yang diinginkan yaitu sebanyak 100 responden. 
Penyebaran kuesioner kepada responden dilakukan dari September hingga Oktober 2020 secara online melalui google form untuk memperoleh data primer. Kemudian untuk mendukung data yang didapat, peneliti juga menggunakan data sekunder yang diambil dari sumber-sumber informasi yang sudah ada sebelumnya, yakni data dari website dan kanal youtube.

Peneliti melakukan uji validitas dan uji reliabilitas guna memastikan instrumen atau dalam hal ini, yaitu kuesioner yang dibuat layak untuk digunakan sebagai alat ukur dalam memperoleh data. Sehubungan dengan data yang diperoleh adalah berupa angka, peneliti melakukan pengolahan data secara statistik dengan bantuan program Statistical Package for Social Science (SPSS). Dalam hal analisis data, peneliti menggunakan analisis statistik deskriptif untuk melakukan pendeskripsian atau penggambaran data yang telah diperoleh tanpa adanya penarikan kesimpulan yang berlaku secara keseluruhan (Sugiyono, 2019). Selain itu, peneliti juga menggunakan analisis regresi linear sederhana untuk mengetahui hubungan secara linear antara variabel independen dan variabel dependen, serta arah hubungan yang diperoleh apakah bersifat positif atau negatif (Septiawan, 2016). Peneliti juga melakukan analisis koefisien determinasi untuk mengetahui seberapa besar kemampuan dari variabel bebas dalam menerangkan variasi pada variabel terikat (Ghazali, 2018).

\section{HASIL DAN PEMBAHASAN}

\section{Data Responden Berdasarkan Jenis Kelamin}

Data responden berdasarkan jenis kelamin yang diperoleh dari penyebaran kuesioner dapat dilihat pada tabel 1.

Tabel 1. Data Responden Berdasarkan Jenis Kelamin

\begin{tabular}{ccc}
\hline Jenis Kelamin & Jumlah & Persentase (\%) \\
\hline Laki-laki & 70 & $70 \%$ \\
Perempuan & 30 & $30 \%$ \\
\hline
\end{tabular}

Meskipun Male.id merupakan brand fashion yang menjual produk pria, tapi ternyata terdapat followers perempuan yang sekadar mengikuti akun Male.id atau bahkan pernah membeli produk yang dijual. Hal ini dibuktikan dengan terdapat responden perempuan yang berpartisipasi dalam penelitian ini, yaitu $30 \%$.

\section{Kategori Variabel Penggunaan Instagram Stories $(\mathrm{X})$}

Berdasarkan perhitungan mengenai lebar interval untuk variabel $X$, diperoleh lima kategori skor yang diklasifikasikan sebagai berikut.

$\begin{array}{ll}\text { Sangat Aktif } & =42-50 \\ \text { Aktif } & =34-41 \\ \text { Cukup Aktif } & =26-33 \\ \text { Kurang Aktif } & =18-25 \\ \text { Tidak Aktif } & =10-17\end{array}$

Peneliti mengolah jawaban responden atas pernyataan-pernyataan pada variabel penggunaan Instagram stories yang telah terkumpul sebelumnya. Kemudian, peneliti melakukan penjabaran dalam bentuk data dan melakukan pengkategorisasian berdasarkan intervalnya seperti pada tabel 2 . 
Tabel 2. Persentase Skor Jawaban Responden untuk Variabel Penggunaan Instagram Stories

\begin{tabular}{cccc}
\hline Kategori & Interval & Frekuensi & Persentase (\%) \\
\hline Sangat Aktif & $42-50$ & 53 & $53 \%$ \\
Aktif & $34-41$ & 36 & $36 \%$ \\
Cukup Aktif & $26-33$ & 7 & $7 \%$ \\
Kurang Aktif & $18-25$ & 3 & $3 \%$ \\
Tidak Aktif & $10-17$ & 1 & $1 \%$ \\
\hline & Jumlah & & $\mathbf{1 0 0}$ \\
\hline
\end{tabular}

Berdasarkan tabel 2, mayoritas responden menilai Male.id telah menggunakan fitur Instagram stories dengan sangat aktif sebagai media dalam melakukan promosi produk maupun berinteraksi dengan followers.

\section{Kategori Variabel Brand Awareness (Y1)}

Melalui perhitungan mengenai lebar interval untuk variabel Y1, diperoleh lima kategori skor yang diklasifikasikan sebagai berikut.

Sangat Baik $=42-50$

$$
\begin{array}{ll}
\text { Baik } & =34-41 \\
\text { Cukup Baik } & =26-33 \\
\text { Kurang Baik } & =18-25 \\
\text { Tidak Baik } & =10-17
\end{array}
$$

Berdasarkan kelima kategori skor yang didapat, peneliti melakukan pengolahan jawaban atas pernyataan-pernyataan pada variabel brand awareness yang telah terkumpul sebelumnya. Kemudian, peneliti melakukan penjabaran dalam bentuk data dan melakukan pengkategorisasian berdasarkan intervalnya seperti pada tabel 3

Tabel 3. Persentase Skor Jawaban Responden untuk Variabel Brand Awareness

\begin{tabular}{cccc}
\hline Kategori & Interval & Frekuensi & Persentase (\%) \\
\hline Sangat Baik & $42-50$ & 32 & $32 \%$ \\
Baik & $34-41$ & 48 & $48 \%$ \\
Cukup Baik & $26-33$ & 14 & $14 \%$ \\
Kurang Baik & $18-25$ & 6 & $6 \%$ \\
Tidak Baik & $10-17$ & 0 & $0 \%$ \\
\hline & Jumlah & & $\mathbf{1 0 0}$ \\
\hline
\end{tabular}

Merujuk pada tabel 3, pembentukan brand awareness atau kesadaran merek pada responden terhadap merek Male.id berada pada kategori baik.

\section{Kategori Variabel Minat Beli (Y2)}

Berdasarkan perhitungan mengenai lebar interval untuk variabel minat beli, diperoleh lima kategori skor yang diklasifikasikan sebagai berikut.

$\begin{array}{ll}\text { Sangat Tinggi } & =53-65 \\ \text { Tinggi } & =43-52\end{array}$

$\begin{array}{ll}\text { Cukup Tinggi } & =33-42 \\ \text { Rendah } & =23-32 \\ \text { Sangat Rendah } & =13-22\end{array}$

Dari perolehan kategori skor yang didapat, peneliti melakukan pengolahan jawaban responden atas pernyataan-pernyataan pada variabel minat beli yang telah terkumpul sebelumnya. Kemudian, peneliti melakukan penjabaran dalam bentuk data dan melakukan pengkategorisasian berdasarkan intervalnya seperti pada tabel 4 
Tabel 4. Persentase Skor Jawaban Responden untuk Variabel Minat Beli

\begin{tabular}{cccc}
\hline Kategori & Interval & Frekuensi & Persentase (\%) \\
\hline Sangat Tinggi & $53-65$ & 14 & $14 \%$ \\
Tinggi & $43-52$ & 28 & $28 \%$ \\
Cukup Tinggi & $33-42$ & 40 & $40 \%$ \\
Rendah & $23-32$ & 16 & $16 \%$ \\
Sangat Rendah & $13-22$ & 2 & $2 \%$ \\
\hline Jumlah & & $\mathbf{1 0 0}$ & $\mathbf{1 0 0 \%}$ \\
\hline
\end{tabular}

Tabel 4 memperlihatkan bahwa responden memiliki minat beli yang cukup tinggi terhadap produk-produk Male.id.

\section{Analisis Regresi Linear Sederhana}

Penelitian ini terdiri atas dua variabel $\mathrm{Y}$ sehingga analisis regresi linear sederhana dilakukan sebanyak dua kali, yaitu antara variabel penggunaan Instagram stories (X) dengan brand awareness (Y1) dan variabel penggunaan Instagram stories (X) dengan minat beli (Y2). Melalui hasil analisis regresi linear sederhana ini, peneliti dapat melihat nilai dari $t_{\text {hitung }}$ dan signifikansi yang diperoleh guna mengetahui seberapa jauh pengaruh variabel bebas secara parsial terhadap variabel terikatnya (Ghazali, 2018: 98), sekaligus untuk menguji hipotesis yang telah disusun dalam penelitian ini apakah diterima atau tidak. Dari hasil analisis ini, peneliti dapat melihat pengaruh dari variabel independen terhadap variabel dependen apakah memiliki arah yang bersifat positif atau negatif.

\section{Analisis Regresi Linear Sederhana Variabel $\mathrm{X}$ dengan Y1}

Melalui hasil pengujian yang diperoleh, dapat dibuat persamaan regresi linear sederhana untuk variabel $\mathrm{X}$ dengan $\mathrm{Y} 1$ sebagai berikut.

$$
\begin{gathered}
\mathrm{Y} 1=\mathrm{a}+\mathrm{bX} \\
\mathrm{Y} 1=9.255+.706(\mathrm{X})
\end{gathered}
$$

Dengan konstanta sebesar 9.255, menunjukkan bahwa apabila penggunaan Instagram stories diabaikan maka brand awareness adalah sebesar 9.255 satuan. Kemudian, jika penggunaan Instagram stories bertambah 1, maka akan menyebabkan kenaikan (karena tanda menunjukkan positif) sebesar .706 pada brand awareness.

Dari perolehan nilai $t_{\text {hitung, }}$ yakni sebesar 8.872 dan signifikansi sebesar .000 yang artinya $<\alpha=.05$, memperlihatkan bahwa terdapat pengaruh yang signifikan antara penggunaan Instagram stories dengan brand awareness. Pengaruh yang diperoleh menunjukkan arah yang bersifat positif, artinya semakin aktif Male.id menggunakan Instagram stories sebagai media dalam melakukan promosi dan melibatkan followers untuk berinteraksi secara online, maka pembentukan brand awareness juga akan semakin baik. Dengan demikian, hasil penelitian ini mendukung diterimanya hipotesis bahwa terdapat efektivitas yang signifikan antara penggunaan Instagram stories pada akun @male.id dengan pembentukan brand awareness di kalangan mahasiswa Universitas Islam Indonesia.

\section{Analisis Regresi Linear Sederhana Variabel $\mathrm{X}$ dengan $\mathrm{Y} 2$}

Berdasarkan hasil pengujian yang diperoleh, dapat dibuat persamaan regresi linear sederhana untuk variabel $\mathrm{X}$ dengan $\mathrm{Y} 2$ sebagai berikut.

$$
\begin{gathered}
\mathrm{Y} 2=\mathrm{a}+\mathrm{bX} \\
\mathrm{Y} 2=12.162+.732(\mathrm{X})
\end{gathered}
$$

Dengan konstanta sebesar 12.162, menunjukkan bahwa apabila penggunaan Instagram stories diabaikan maka minat beli adalah sebesar 12.162 satuan. Kemudian, jika penggunaan Instagram stories bertambah 1, maka akan menyebabkan kenaikan (karena 
tanda menunjukkan positif) sebesar .732 pada minat beli.

Melalui hasil pengujian yang dilakukan, dapat diketahui nilai $t_{\text {hitung }}$ yang diperoleh adalah sebesar 5.939 dan signifikansi sebesar $.000(<\alpha=.05)$. Ini menunjukkan bahwa terdapat pengaruh yang signifikan antara penggunaan Instagram stories dengan minat beli. Pengaruh yang muncul memiliki arah yang bersifat positif. Ini mengartikan bahwa semakin aktif Male.id menggunakan Instagram stories sebagai media dalam melakukan promosi dan melibatkan followers untuk berinteraksi secara online, minat beli oleh konsumen terhadap produk Male.id juga akan semakin tinggi. Dengan demikian, hasil penelitian menunjukkan bahwa hipotesis yang menyatakan adanya efektivitas yang signifikan antara penggunaan Instagram stories pada akun @male.id dengan minat beli di kalangan mahasiswa Universitas Islam Indonesia dapat diterima.

\section{Analisis Koefisien Determinasi}

Merujuk pada hasil analisis yang diperoleh, dapat diketahui bahwa variabel penggunaan Instagram stories mampu menjelaskan atau mempengaruhi nilai variabel brand awareness sebesar .445 atau 44.5\%, sedangkan $55.5 \%$ sisanya dipengaruhi oleh faktor lain yang belum dimasukkan ke dalam penelitian ini. Sementara itu, untuk variabel minat beli, dipengaruhi oleh variabel penggunaan Instagram stories sebesar 26.5\%, sedangkan $73.5 \%$ lainnya dipengaruhi oleh faktor lain di luar variabel $\mathrm{X}$ yang belum dimasukkan ke dalam penelitian ini.

\section{Efektivitas Penggunaan Instagram Stories} pada Akun@male.id terhadap Pembentukan Brand Awareness di Kalangan Mahasiswa Universitas Islam Indonesia

Sebagai brand fashion pria, Male.id aktif menggunakan fitur Instagram stories sebagai media dalam melakukan promosi produknya. Selain itu, Male.id juga menggunakan fitur Instagram stories untuk melibatkan pengikutnya dalam berinteraksi secara online. Ini dilakukan agar mampu mencapai tujuan pemasaran yang diinginkan.

Male.id melakukan interaksi dengan followers, yaitu dengan menggunakan pola interaksi yang diadaptasi dari para influencer, kemudian diterapkan di Male.id (Brodo, 2020). Interaksi yang dilakukan melalui Instagram stories biasanya menampilkan screenshot-an direct message (DM) berupa honest review (testimoni) hingga pertanyaan dari followers yang kemudian ditambahkan teks sebagai balasan untuk DM tersebut. Selain itu, Male.id juga memanfaatkan fitur question box di Instagram stories untuk tanya jawab atau sharing seputar Male.id maupun hal lainnya sehingga membuat Male.id memiliki engagement cukup baik dengan followers, di mana Male.id sangat aktif melibatkan konsumen untuk berinteraksi secara online melalui Instagram stories. Penggunaan Instagram stories sebagai sarana untuk menyampaikan atau mengenalkan produk serta melibatkan followers untuk berinteraksi secara online, diharapkan dapat membentuk brand awareness atau kesadaran terdahap merek Male.id.

Penelitian ini menunjukkan bahwa setiap tingkatan brand awareness telah terjadi pada responden. Mulai dari tingkatan pertama, yaitu unaware of brand, di mana pada tingkatan ini responden tidak mengetahui merek Male.id itu sendiri maupun sesuatu yang berkaitan dengan Male.id seperti tagline maupun nama produk legendaris yang menjadi andalan di Male.id. Namun, untuk tingkatan yang pertama ini, hanya terjadi pada minoritas responden karena mayoritas responden telah mengetahui merek Male.id maupun sesuatu yang berkaitan dengan Male.id.

Tingkatan berikutnya adalah brand recognition. Pada tingkatan ini, responden mengenali merek Male.id dari ciri-ciri produknya seperti nama hingga tampilan visual atau desain dari produk Male.id itu sendiri.

Tingkatan yang ketiga adalah brand recall. Pada tingkatan ini, responden telah 
mengingat Male.id sebagai kategori produk fashion pria. Tingkatan terakhir adalah top of mind. Pada tingkatan ini, responden menjadikan Male.id sebagai merek yang pertama kali disebut atau diingat sebagai kategori produk fashion pria.

Melalui hasil uji pengaruh yang dilakukan, dapat diketahui bahwa nilai $t_{\text {hitung }}$ yang didapatkan adalah sebesar 8.872 dan signifikansi sebesar .000 artinya $<\alpha=0,05$. Ini memperlihatkan bahwa terdapat efektivitas yang signifikan antara penggunaan Instagram stories pada akun @male.id dengan pembentukan brand awareness di kalangan mahasiswa Universitas Islam Indonesia. Besarnya tingkat keefektivan penggunaan Instagram stories terhadap pembentukan brand awareness dapat dilihat melalui kolom $\mathrm{R}$ Square pada analisis koefisien determinasi, di mana nilai $\mathrm{R}$ Square yang didapatkan, yaitu sebesar .445, artinya tingkat keefektivan penggunaan Instagram stories terhadap pembentukan brand awareness adalah sebesar $44.5 \%$.

Sehubungan dengan hasil yang diperoleh pada penelitian ini, penelitian terdahulu yang dilakukan oleh Kristiawan (2015) terkait pengaruh pemasaran melalui media sosial terhadap kesadaran konsumen pada produk internasional (Uniqlo), menunjukkan bahwa pemasaran melalui media sosial dapat memberitahukan keberadaan mereka (Uniqlo) kepada khalayak atau mampu menciptakan kesadaran konsumen terhadap merek Uniqlo. Selain itu, penelitian tersebut memperlihatkan bahwa customer engagement atau keterlibatan konsumen dalam berinteraksi juga memberikan pengaruh yang signifikan terhadap kesadaran konsumen atas sebuah merek. Dengan demikian, temuan yang diperoleh pada penelitian ini serupa dan mampu mendukung penelitian terdahulu yang digunakan.

\section{Efektivitas Penggunaan Instagram Stories pada Akun @ male.id terhadap Minat Beli di Kalangan Mahasiswa Universitas Islam Indonesia}

Penggunaan Instagram stories sebagai media dalam mempromosikan produk maupun berinteraksi dengan followers secara online, diharapkan dapat menarik perhatian followers untuk mengenal lebih dalam terkait sebuah brand maupun produk-produk yang ditawarkan. Sehingga nantinya selain akan membentuk brand awareness, juga akan menimbulkan minat beli di dalam diri followers, kemudian akan mendorong followers untuk melakukan tindakan berupa pembelian produk dari brand tersebut.

Seperti yang diketahui, keaktifan Male.id dalam menggunakan Instagram stories terbukti mampu menimbulkan minat beli pada konsumen terhadap produk-produk Male.id. Hal ini ditunjukkan melalui jawaban responden yang diperoleh. Berdasarkan jawaban responden, dapat dikatakan bahwa responden telah menaruh perhatian pada iklan atau pesan yang disampaikan oleh Male.id melalui Instagram stories. Perhatian tersebut mampu menimbulkan ketertarikan responden terhadap produk-produk yang ditawarkan, hingga sampai pada tahap di mana responden dapat melakukan tindakan berupa pembelian terhadap produk dari Male.id.

Minat beli yang timbul pada responden didukung oleh model AISAS yang terdiri atas attention (perhatian), interest (ketertarikan), search (pencarian), action (aksi), dan share (berbagi). Berdasarkan temuan yang diperoleh, model AISAS mampu mendukung konsumen dalam menggunakan media baru sebagai sarana untuk mengetahui produk dari Male.id. Ini akan menimbulkan suatu tindakan terhadap produk tersebut. 
Penelitian ini juga menunjukkan bahwa responden telah menaruh perhatian (attention) terhadap apa yang disampaikan Male.id melalui Instagram stories. Selanjutnya, masuk ke tahap berikutnya yaitu timbulnya ketertarikan (interest), di mana setelah responden melihat produk yang disampaikan oleh Male.id melalui Instagram stories, akan timbul rasa ketertarikan serta memiliki keinginan untuk mengetahui lebih lanjut terhadap produk-produk yang ditawarkan tersebut. Tahap berikutnya adalah tahap pencarian (search), di mana dari rasa ingin tahu yang telah timbul sebelumnya akan mendorong responden untuk melakukan pencarian melalui mesin pencari atau melalui media sosial pribadi. Setelah mendapatkan informasi yang cukup terkait produk dari Male.id, berkembang ke tahap aksi (action). Pada tahap ini, responden melakukan tindakan yang mendukung untuk memperoleh produk yang diinginkan seperti dengan melakukan pembelian terhadap produk tersebut. Setelah mendapatkan produk yang diinginkan, responden akan merasakan pengalaman yang didapatkan, baik terkait produk yang dibeli maupun pengalaman interaksi yang dilakukan. Berdasarkan pengalaman tersebut, akan mendorong responden untuk berbagi (share) pengalamannya kepada orang lain, baik di dunia nyata maupun secara online melalui media sosial.

Berdasarkan hasil uji pengaruh yang dilakukan, nilai $t_{\text {hitung }}$ yang didapatkan adalah sebesar 5.939 dan signifikansi sebesar .000 artinya $<\alpha=.05$. Ini memperlihatkan bahwa terdapat efektivitas yang signifikan antara penggunaan Instagram stories pada akun @male.id dengan minat beli di kalangan mahasiswa Universitas Islam Indonesia. Besarnya tingkat keefektivan penggunaan Instagram stories terhadap minat beli dapat dilihat melalui kolom $\mathrm{R}$ Square pada analisis koefisien determinasi, di mana nilai $\mathrm{R}$ Square yang didapatkan yaitu sebesar .265, artinya tingkat keefektivan penggunaan Instagram stories terhadap minat beli adalah sebesar $26.5 \%$. Meskipun nilai yang diperoleh hanya sebesar $26.5 \%$, tetapi perolehan nilai tersebut sudah mampu membuktikan bahwa minat beli yang muncul pada responden dapat terjadi karena keaktifan Male.id dalam menggunakan Instagram stories sebagai media untuk melakukan promosi produk maupun berinteraksi dengan followers.

Penelitian ini memperlihatkan bahwa minat beli berdasarkan tahapan AISAS telah dialami oleh responden. Hal ini ditunjukkan oleh perolehan jawaban responden pada kuesioner penelitian, di mana jawaban yang diberikan mampu mendukung tahapan yang dialami oleh responden sehingga dapat menimbulkan minat beli pada responden terhadap produk Male.id. Berkaitan dengan hal tersebut, penelitian terdahulu yang dilakukan oleh Septiawan, (2016) mengenai hubungan antara efektifitas media sosial Instagram dengan minat beli sepatu sneaker, menunjukkan bahwa terdapat hubungan yang signifikan dan positif antara efektivitas media sosial Instagram dengan minat beli sepatu sneaker. Dengan demikian, temuan penelitian ini mampu mendukung dan mengembangkan penelitian terdahulu di mana minat beli pada konsumen juga dapat terbentuk dengan melibatkan followers/konsumen untuk berinteraksi secara online melalui penggunaan fitur Instagram stories.

Secara keseluruhan, dapat diketahui melalui uji regresi linear bahwa penggunaan Instagram stories pada akun@male.id efektif secara signifikan terhadap pembentukan brand awareness dan minat beli. Kemudian arah pengaruh antara variabel $\mathrm{X}$ dengan $\mathrm{Y} 1$ dan $\mathrm{X}$ dengan Y2 yang ditunjukkan adalah bersifat positif. Ini menandakan bahwa semakin aktif Male.id menggunakan Instagram stories sebagai media untuk mengenalkan atau mempromosikan produk serta untuk melibatkan followers dalam berinteraksi secara online, maka pembentukan brand awareness di kalangan mahasiswa Universitas Islam Indonesia juga semakin baik. Demikian juga, minat beli di kalangan mahasiswa Universitas Islam Indonesia juga semakin tinggi. 


\section{KESIMPULAN}

Berdasarkan hasil penelitian ini, dapat disimpulkan bahwa penggunaan Instagram stories yang dilakukan secara aktif oleh Male.id sebagai media untuk melakukan promosi produk maupun untuk melibatkan followers dalam berinteraksi secara online, mampu mendukung terbentuknya brand awareness di kalangan mahasiswa Universitas Islam Indonesia. Selain itu, Penggunaan Instagram stories yang dilakukan secara aktif oleh Male.id juga mampu menimbulkan minat beli di kalangan mahasiswa Universitas Islam Indonesia. Meskipun tingkat keefektivan penggunaan Instagram stories terhadap minat beli yang diperoleh cenderung rendah, yaitu sebesar $26.5 \%$, tapi nilai tersebut sudah mampu membuktikan bahwa minat beli yang muncul pada responden dapat terjadi karena keaktifan Male.id dalam menggunakan Instagram stories sebagai media untuk melakukan promosi produk maupun berinteraksi dengan followers secara online.
Keseluruhan penelitian ini menunjukkan bahwa apa yang dilakukan Male.id sudah tepat dalam menggunakan Instagram stories sebagai media untuk melakukan promosi produk maupun untuk melibatkan followers dalam berinteraksi secara online. Oleh karena itu, perlu dipertahankan dan ditingkatkan agar pembentukan brand awareness pada konsumen semakin baik dan minat beli pada konsumen juga semakin tinggi.

Dengan melihat tingkat keefektivan penggunaan Instagram stories terhadap brand awareness maupun terhadap minat beli pada penelitian ini, maka pemilik brand lain dapat mempertimbangkan penggunaan Instagram stories untuk meningkatkan pembentukan brand awareness dan minat beli pada konsumen.

Di samping itu, temuan penelitian ini juga menunjukkan bahwa terdapat responden perempuan yang turut berpartisipasi dalam penelitian ini. Ini dapat menjadi topik yang menarik untuk dikaji bagi peneliti selanjutnya. 


\section{DAFTAR PUSTAKA}

Aditi, B., \& Hermansyur, H. (2018). Pengaruh atribut produk, kualitas produk dan promosi, terhadap keputusan pembelian mobil merek honda di Kota Medan. Jurnal Ilmiah Manajemen Dan Bisnis, 19(1), 64-72.

https://doi.org/10.30596/jimb.v19i1.1743

Anatasya, E. (2018). Peranan persepsi kualitas website terhadap persepsi kualitas produk dan minat beli produk fashion secara online (Studi pada Mahasiswa UII Yogyakarta) [Universitas Islam Indonesia]. https://dspace.uii.ac.id/handle/123456789 $/ 12552$

Anjani, P. P. (2019). Pengaruh efektivitas konten media sosial instagram @ BLPBeauty terhadap tingkat minat beli produk [Universitas Multimedia Nusantara Tangerang]. https://kc.umn.ac.id/10151/8/HALAMA N_AWAL.pdf

Ardiansyah, R. (2016). Analisis faktor-faktor yang mempengaruhi minat beli online shop konsumen (Studi kasus pada mahasiswa di Universitas Islam Indonesia) [Universitas Islam Indonesia, Yogyakarta].

https://dspace.uii.ac.id/handle/123456789 12737

Arifin, N. (2015). Strategi pemasaran dan minat beli (Studi korelasional tentang strategi pemasaran brodo footwear melalui instagram dan minat beli mahasiswa FISIP USU. Jurnal Simbolika, 1(2), 1-8. https://docplayer.info/48701921-Strategipemasaran-dan-minat-beli-studikorelasional-tentang-strategi-pemasaranbrodo-footwear-melalui-dan-minat-belimahasiswa-fisip-usu.html

Brodo. (2020). Collaborative talk with Male.id. YouTube.

https://www.youtube.com/watch? $\mathrm{v}=\mathrm{akSa}$ Mra_gWY

Fauzi, V. P., \& Lubis, E. E. (2016).

Pemanfaatan instagram sebagai social media marketing er-corner boutique dalam membangun brand awareness di Kota Pekanbaru. Jurnal Online Mahasiswa FISIP, 3(1). https://jom.unri.ac.id/index.php/JOMFSI
P/article/view/9366

Ghazali, I. (2018). Aplikasi analisis multivariate dengan program IMB SPSS 25. In Badan Penerbit UNDIP.

Kristiawan, D. I. (2015). Pengaruh pemasaran melalui media sosial terhadap kesadaran konsumen pada produk internasional (Studi pada pengguna produk Uniqlo di Indonesia). Jurnal Administrasi Bisnis, 24(1). http://administrasibisnis.studentjournal.u b.ac.id/index.php/jab/article/view/938

Kusumasari, P. W. (2018). Peran online engagement pada pengaruh tipe post dan waktu post di instagram terhadap minat beli (Studi kasus pada online shop @ cheesycrazysolo) [Universitas Sanata Dharma Yogyakarta]. https://repository.usd.ac.id/28651/2/1422 14173_full.pdf

Miranda, S., \& Lubis, E. E. (2017). Pengaruh instagram sebagai media online shopping fashion terhadap perilaku konsumtif mahasiswi Fakultas Ilmu Sosial dan Ilmu Politik Universitas Riau. Jurnal Online Mahasiswa FISIP, 4(1).

Nafisah. (2018). Pengaruh strategi promosi melalui social media terhadap minat beli konsumen (Studi kasus pada produk pakaian wanita Aris Grosir di kabupaten Bantul) [Sekolah Tinggi Ilmu Ekonomi Widya Wiwaha Yogyakarta]. http://eprint.stieww.ac.id/713/

Oktavia, F. (2019). Studi komparatif mengenai word of mouth dan minat beli pada pusat oleh-oleh pempek Candy dan pempek Vico Palembang. Expose: Jurnal Ilmu Komunikasi, 2(1), 49. https://doi.org/10.33021/exp.v2i1.547

Pranata, I. W. D. R., \& Pramudana, K. A. S. (2018). Peran kesadaran merek (Brand Awareness) dalam memediasi hubungan iklan Oppo dengan niat beli konsumen. E-Jurnal Manajemen Universitas Udayana, 7(10), 5230. https://doi.org/10.24843/EJMUNUD.201 8.v07.i10.p02

Septiawan, M. F. (2016). Hubungan antara efektifitas media sosial instagram dengan minat beli sepatu sneaker (Survei pada mahasiswa FISIP pengguna media sosial instagram di follower account official 
[Universitas Sultan Ageng Tirtayasa].

http://eprints.untirta.ac.id/692/

Sugiyono. (2019). Metode penelitian

kuantitatif, kualitatif, dan $R \& D$.

Alfabeta.

Tanjaya, E. (2017). Efektifitas media sosial instagram terhadap kesadaran merek Dr.Churros. Jurnal Performa, 2(4).

https://journal.uc.ac.id/index.php/perfor $\mathrm{ma} /$ article/view/583 